\title{
CARDIOLOGY CENTRE PATIENTS' AWARENESS OF THE NEGATIVE EFFECTS OF TRANS FATTY ACIDS ON CARDIOVASCULAR DISEASES
}

\author{
Lāsma Plociṇa ${ }^{1, \#}$ and Iveta Mintāle ${ }^{2}$ \\ ${ }^{1}$ Rīga 2nd Hospital, 1 G̣imnastikas Str., Rīga, LV-1004, LATVIA \\ 2 Pauls Stradinš Clinical University Hospital, 13 Pilsoṇu Str., Rīga, LV-1002, LATVIA \\ \# Corresponding author, lasmina-n@ inbox.lv
}

Communicated by Andrejs Ërglis

\begin{abstract}
It is very important to promote public awareness of the negative effects on health - trans fatty acid effects on cardiovascular disease. The study included 70 patients of the Latvian Centre of Cardiology, Pauls Stradinš Clinical University Hospital (PSCUH). The PSCUH research institute gave permission to conduct the study. The patients answered questions about their awareness of trans fatty acids. The questionnaire used was obtained from the study "Use of Trans Fat Information on Food Labels and Its Determinants in a Multiethnic College Student Population" and modified for survey of the cardiology unit patients. The majority (74\%) of the respondents had heard and read something about trans fatty acids, but $62 \%$ women and $54 \%$ men were poorly informed about trans fatty acids and their negative effect on cardiovascular diseases. Unclear issues for patients were discussed after the questionnaire.
\end{abstract}

Key words: trans fatty acids (TFA), cardiovascular disease (CVD), coronary heart disease (CHD), the effect of awareness.

\section{INTRODUCTION}

The daily rhythm of people is very rapid - waking up early in the morning, cooking breakfast for oneself and one's family, work, which comes together with stress and replacement of proper meals with fast food. In the course of time, traditions like cooking and eating warm, homemade meals are forgotten.

Data of the Centre for Disease Prevention and Control (CDPC) of Latvia indicate that there is an increasing number of people who, instead of eating healthy food, replace it with pastry, which is not a wholesome diet, but more like a snack (Pudule et al., 2010). Pastry includes products that potentially contain trans fatty acids (polyunsaturated and monounsaturated fatty acid isomers, which originate mainly during the oil hydrogenation process (especially while heating) (Mintāle et al., 2010).

Unsaturated fatty acids have two types of isomers - geometric and positional, which differ in a double bond position. The geometric isomer typically has at least one double bond, for example, cis configuration with molecular arrangement in a "V" form. This type of double bond arrangement provides the stability of the molecule (Stender et al., 2014). When long carbon chains of fatty acids are trans- formed during the trans configuration, it is common to have a straightened molecule with hydrogen atoms arranged on opposite sides, as in Figure 1. The melting point of oleic acid is $14{ }^{\circ} \mathrm{C}$, but of trans form elaidic acid $-45{ }^{\circ} \mathrm{C}$ (Stender et al., 2014).

Daily use of these products that contain trans fatty acids (TFA), over the course of a couple of years, can cause serious and incurable illnesses, cardiovascular disease (CVD) being one of them.

According to the CDPC data, cardiovascular disease was the most common cause of death (54\% of all deaths) in Lat-
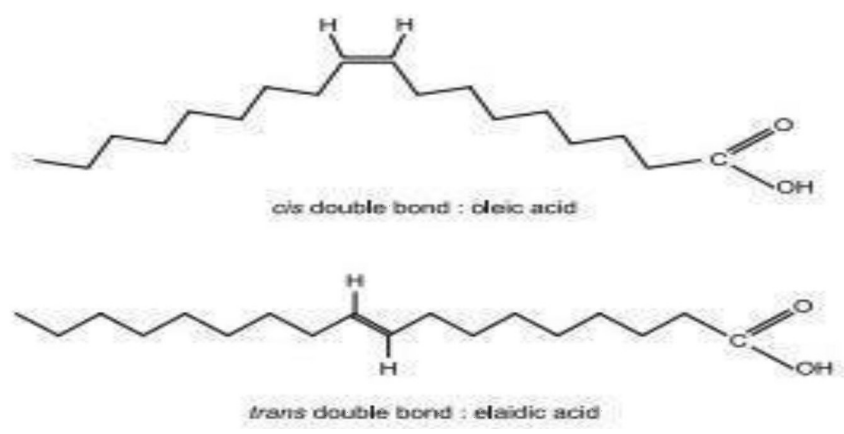

Fig. 1. Structural formula of the trans fatty acids. (Stender et al., 2014). 
via in 2012. The number of CVD has a tendency to increase with each year. The total number of deaths annually is approximately 16000 (16 313 in 2012), one-fifth of whom have died before the age of 64 (Database of Latvian population causes of death, CDPC); furthermore, standardised mortality (until the age of 64) caused by cardiovascular disease in Latvia is three times higher than in EU countries and other Baltic countries on average (Pudule et al., 2010).

Use of food with trans fatty acids can raise the total blood cholesterol level by $20-30 \%$ as well as increase the proportion of "bad cholesterol" (LDL-C) and lower the proportion of "good cholesterol" (HDL-C) (Trumbo and Shimakawa, 2011; Iqbal et al., 2014).

Trans fatty acids are not synthesised in the human body, and thus use of trans fatty acids in the diet for several years can cause development of inflammatory processes in arteries, which are risk factors in the development of cardiovascular diseases. Meta-analysis studies have found that the risk of developing CHD increases by about $23 \%$ if on average $5 \mathrm{~g}$ trans fatty acids are used daily, which corresponds to $2 \%$ of the total energy consumption). Other studies show that when the proportion of trans fatty acids in the diet is $1 \%$, the risk to increase the level of "bad cholesterol" increases (Paula, 2011; Stender et al., 2014).

Many epidemiological and clinical trials on animals and in vitro have demonstrated the negative effect of industrially synthesised TFA on coronary heart disease, as well as the body's physiological mechanisms and cellular malfunctions (Ascherio et al., 1994). By altering the cell activity, endothelial dysfunction is provoked, which is the first step to atherosclerosis formation (Stender and Dyerleeng, 2004).

The World Health Organisation (WHO) and the European Food Safety Authority (EFSA) have developed suggestions/ recommendations for acceding countries for provision of healthy and balanced nutrition. In 2002, the WHO established that daily food consumption by a person should not exceed trans fatty acids at a level of more than $1 \%$ of the daily caloric value intake (Stender et al., 2014). The Euro- pean Food Safety Authority (EFSA) suggests EU acceding countries to decrease trans fatty acids in food products to a minimum (Krettek, 2008).

We cannot yet choose our genealogy, but we can choose our lifestyle, and despite our rapid rhythm of life, we ought to think about ourselves and about the food we "feed" our organism with, because often food that is the most appealing to us is not the healthy choice. It should not be forgotten that nutrition is a part of our life and the foundation of good health. Food prepared at home and made healthy will always be better than shop-bought ready prepared foods, because not everything that we can find in the shops is healthy and "friendly" for us and our organism.

The aim of the research was to determine the level of awareness among patients of the cardiology department regarding trans fatty acids and their negative impact on cardiovascular diseases.

\section{MATERIALS AND METHODS}

The quantitative and non-experimental study included 70 patients of the Latvian Centre of Cardiology, Pauls Stradiňš Clinical University Hospital. The average age of the respondents was 68 years (see Fig. 2). The Cardiac Research Institute had authorised the study. The research period was three months. The study was conducted according to the declaration of the Helsinki ethical standards and the legislation of the Republic of Latvia. The participants of the research were not exposed to any risk that could endanger their health, well-being or personal data security. The data obtained was confidential and was used only in a summarised way.

A questionnaire was used to obtain information from patients. The questionnaire consisted of 20 questions, which included demographic questions (age, sex, place of the residence), the clinical diagnosis of the patient and the duration of the disease; one question on whether it is important to the patient to eat healthily, four questions on awareness of the
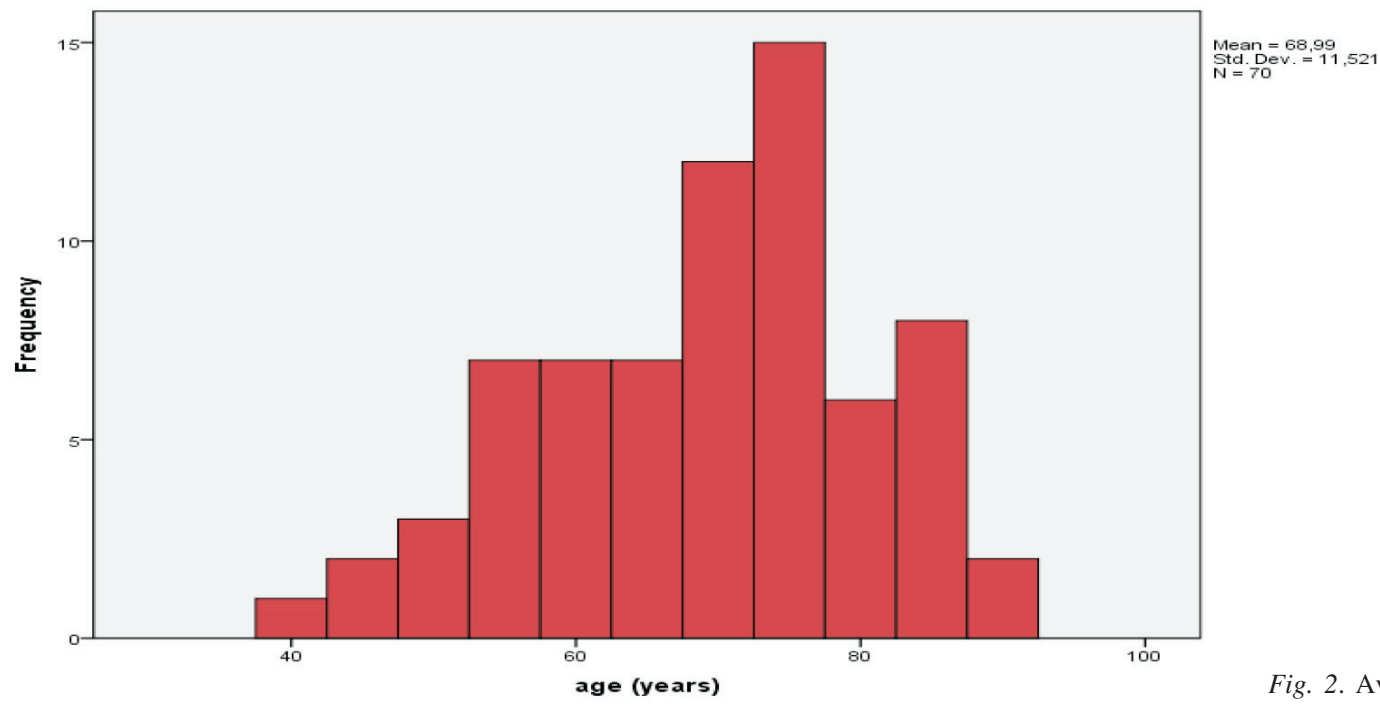

Fig. 2. Average age of the respondents. 
patient regarding trans fatty acids, four questions on awareness of the effect of trans fatty acids on health and six questions on presence of trans fatty acids in food products.

The questions about patient awareness on trans fatty acids were taken from a questionnaire used in the study "Use of Trans Fat Information on Food Labels and Its Determinants in a Multiethnic College Student Population" (Jasti and Kovacs, 2010). The questionnaire was modified for survey of the cardiology unit patients.

An electronic authorisation for the study was received regarding the usage of the questionnaire.

Potential participants of the research received an invitation to take part in the research, with the help of the informative letter. The 70 cardiology patients participating in the study already had a cardiac diagnosis. They each answered the questions in the questionnaire in the presence of the researcher. The time taken to complete the questionnaire was approximately 21 minutes. In case of uncertainty of a patient regarding a question, the researcher gave additional information. At the end of the questionnaire, the researcher individually discussed uncertain questions with the patient as well as answered the patients' questions.

The data collected from the questionnaire were summarised and processed using SPSS software (IMB SPSS Statistic 22) and Microsoft Excel. Mathematical statistics and functions used in the process were: averages, standard deviation, minima and maxima. Relationships were tested using a correlation analysis was used. Visual graphs were created using softwares which reflected and made the results collected from the questionnaires far more apparent/clearer.

\section{RESULTS}

Answers to questions regarding the diagnosis and its detection are shown in Figure 3. In the period till 2000, three respondents were diagnosed with MI (myocardial infarction), and one each with atherosclerosis, hypertension, and heart failure. In the period from 2000 to 2005, there were no pa- tients diagnosed with any disease. From 2005 to 2010, three patients were diagnosed with hypertension, two patients with myocardial infarction, and one each with a clot in a blood vessel, heart failure, and angina. In the period from 2010 to 2016 , the number of the patients increased: hypertension -5 , heart rhythm disorders -5 , myocardial infarction - 9 , clot in a blood vessel -2 , angina pectoris 8 , heart failure - 4, and atherosclerosis - 4. A low number of the patients were diagnosed with stroke -2 , heart pathologies - 2, and cardiac arrhythmias - 2. Eight patients did not know the time of their diagnosis detection (see Fig. 3).

Evaluating the distribution based on the detected diagnosis, only four diagnosed patients were under the age of 50. In the age group 50-60, three patients were diagnosed with myocardial infarction, two with hypertension, two with heart valve pathologies, two with heart rhythm disorder cases, and one respondent had angina. In the age group 60-70, three respondents were diagnosed with angina, three with atherosclerosis, one with stroke, one with heart failure, one with heart rhythm disorders, one with clot in a blood vessel, and four patients with myocardial infarction. In the age group 70-80, three respondents were diagnosed with heart rhythm disorders, three with stroke, and three with atherosclerosis. Two patients had cardiac arrhythmia, six patients had angina, five were with hypertension, and five with myocardial infarction. In the age group 80-90, three respondents were diagnosed with cardiac valvular pathology, three with cardiac arrhythmia, and three with thromboembolism. Also, cardiac valvular pathology, heart failure, myocardial infarction, and atherosclerosis were each diagnosed in three patients (Fig. 4).

$4.3 \%$ men and women answered that it is not important to eat healthy, but the largest part of patients $(42.8 \%$ of men and $48.5 \%$ of women answered that it is really important to eat healthy food (Fig. 5).

To the question about trans fatty acid effect on HDL-C, $42.9 \%$ of respondents answered that trans fatty acids do not increase "good cholesterol", $11.4 \%$ of respondents said that

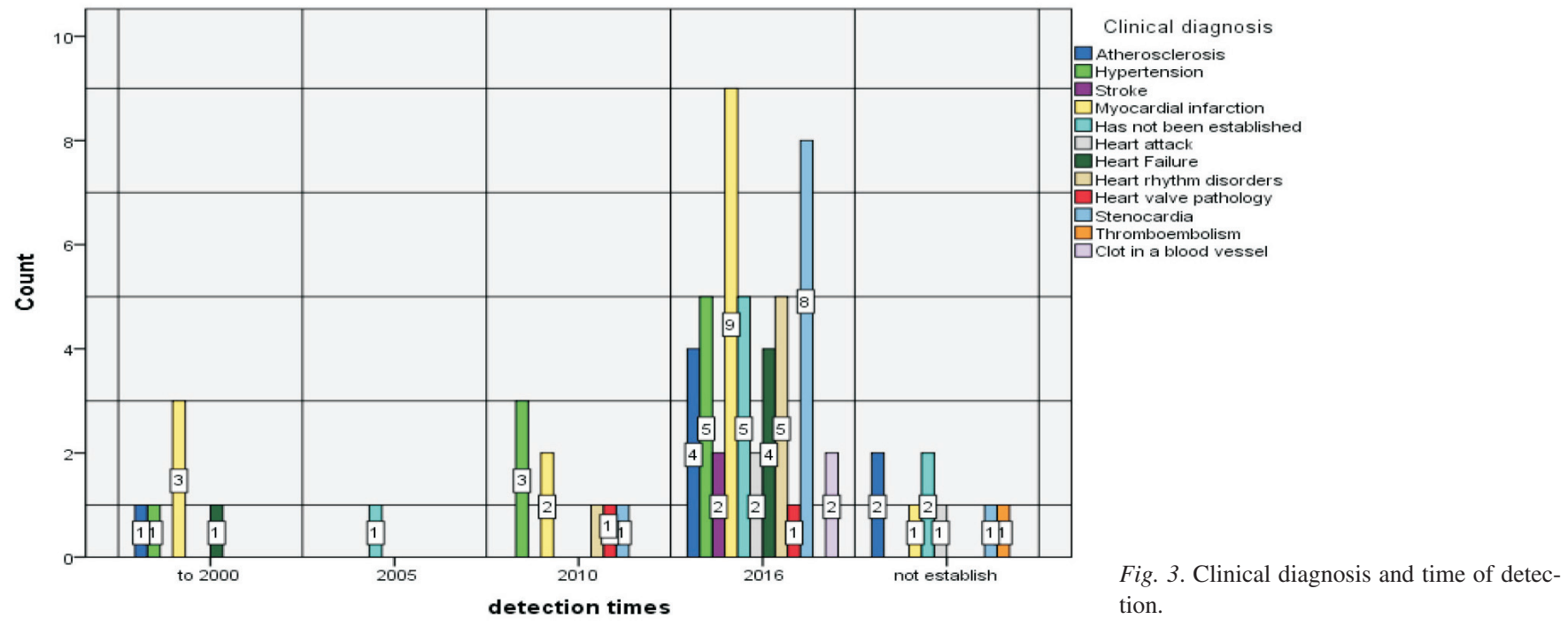




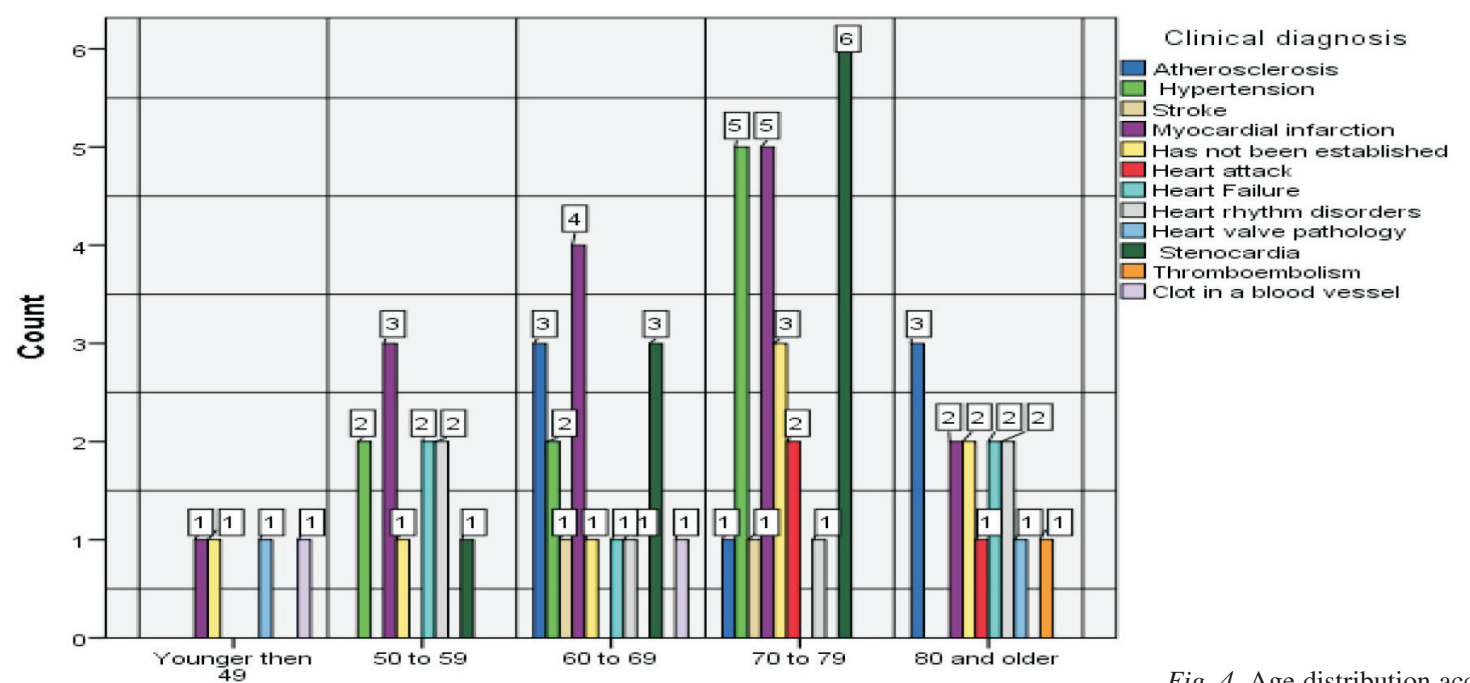

Fig. 4. Age distribution according to the detected di-

Age (years) agnosis.

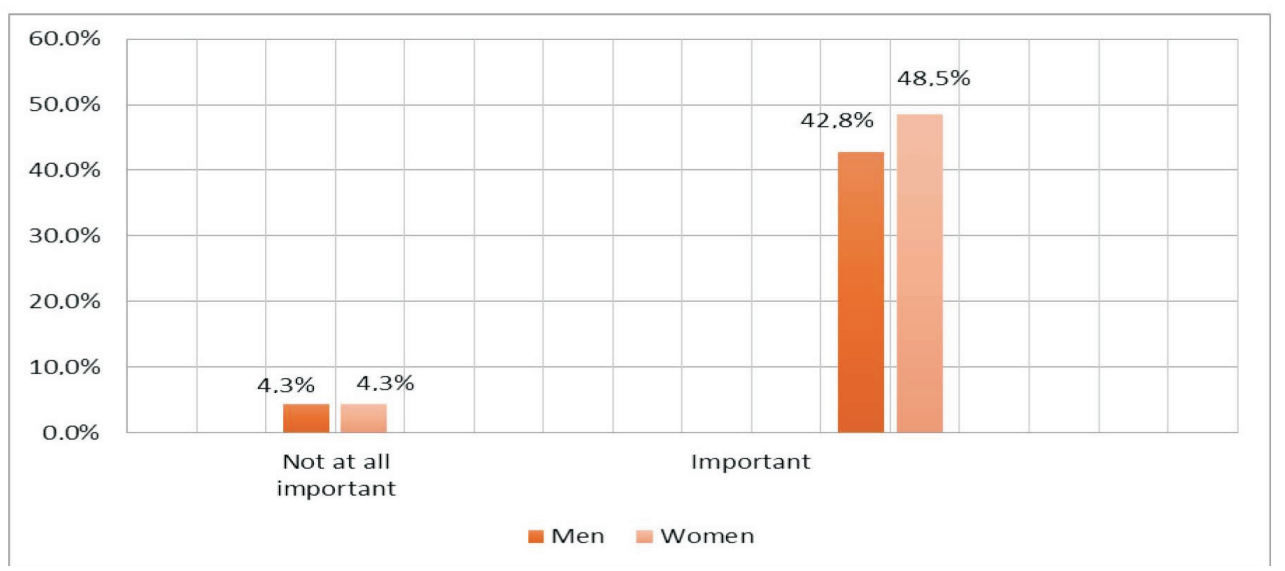

Fig. 5. How well informed of trans fatty acids are you?

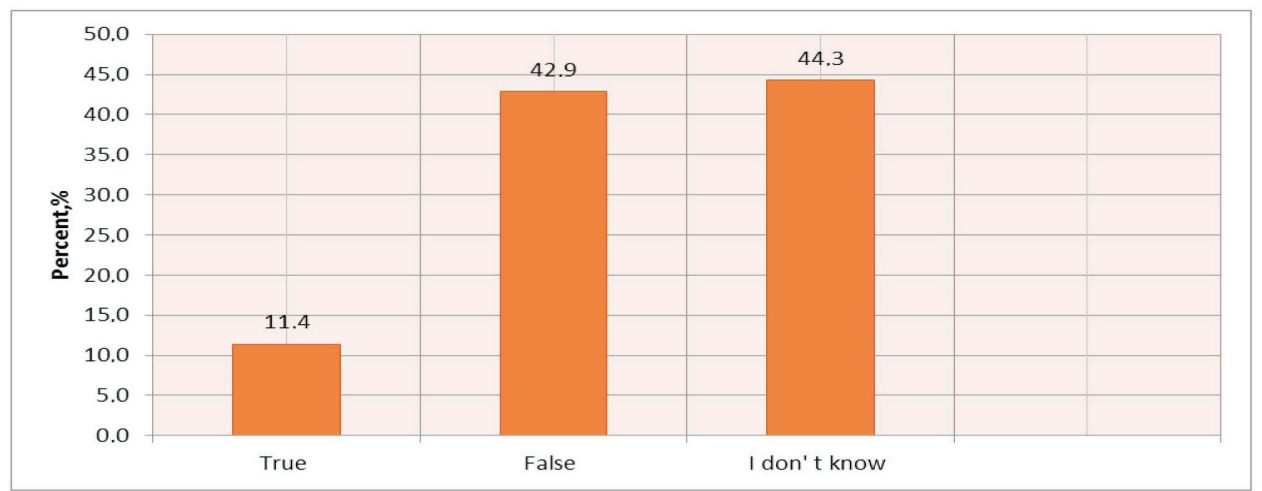

Fig. 6. Do trans fatty acids increase HDL-C ('good cholesterol)'?

they increase HDL-C and $44.3 \%$ of respondents did not know the answer (Fig. 6).

$21.4 \%$ of the respondents thought that trans fatty acids decrease LDL-C, $35.7 \%$ of respondents answered that trans fatty acids increase LDL-C and $42.9 \%$ of respondents did not know the answer (Fig. 7).

$60 \%$ of respondents thought that manufacturers should show the presence of trans fatty acids on food products, $10 \%$ believed that they should not and $27.1 \%$ did not know (Fig. 8).
To the final question of the questionnaire, the vast majority of respondents $(82.9 \%)$ answered that indication of trans fatty acids content on the food products packaging would make them consider a better and more qualitative food choice, $5.7 \%$ noted that it would not change their purchasing choice and $11.4 \%$ did not know whether their thoughts would change in the event that they saw food products with the indication of the presence of trans fatty acid (Fig. 9).

\section{DISCUSSION}

Respondents were given and asked to complete a questionnaire, to determine their awareness of TFA and its effect of 

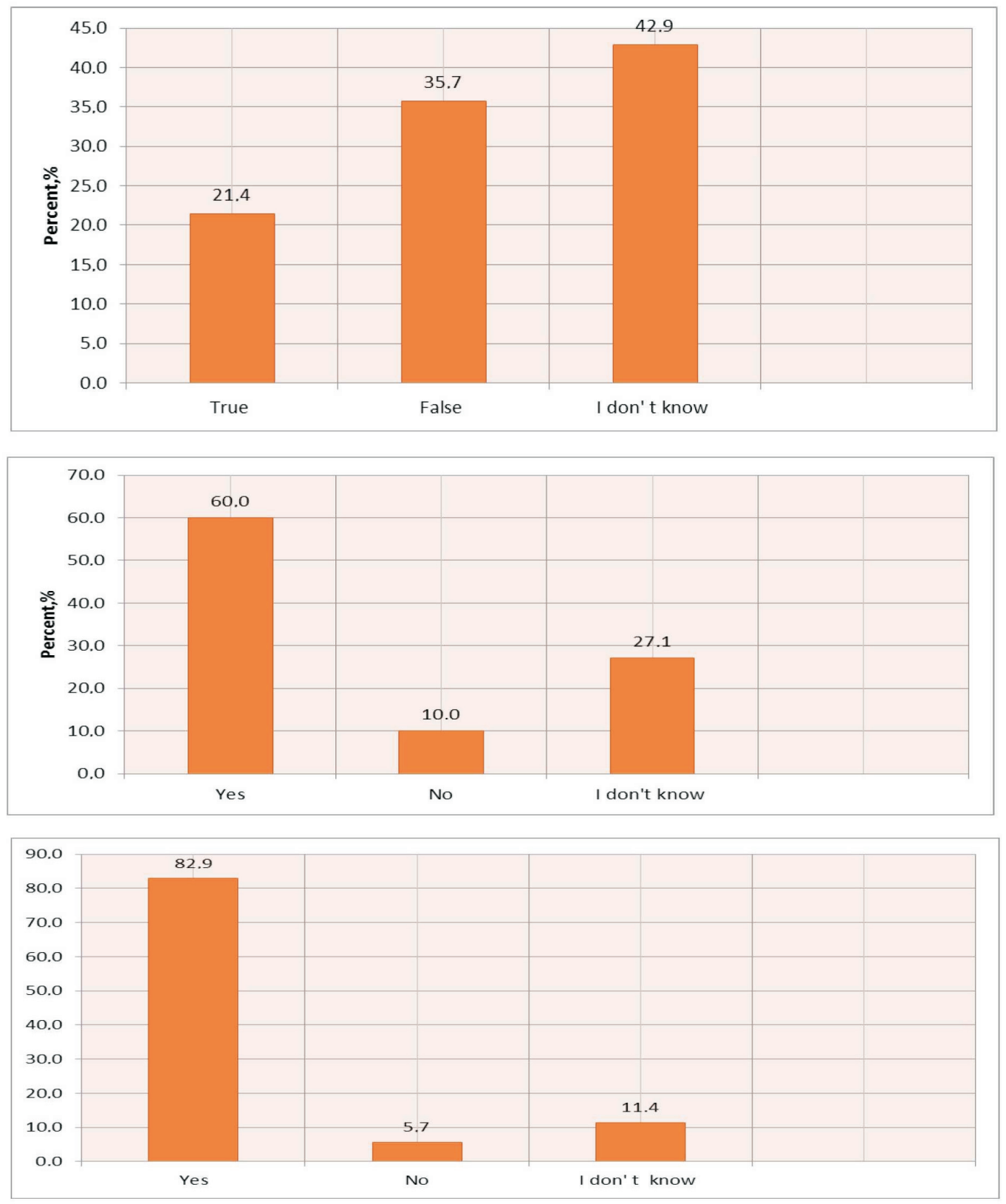

Fig. 7. Do trans fatty acids decrease LDL-C ("bad cholesterol')?

Fig. 8. Do you think the manufacturers should be required to show the presence of trans fatty acids on food products?

Fig. 9. Would trans fatty acid indication on the food products make you consider a better / more qualitative food choice? health, and specifically, its effect upon cardiovascular health and CVD. During the completion of the questionnaire, the researcher answered any technical questions the respondents had, but did not provide information that would influence their answer to the questions.

The greatest number of respondents with a diagnosis recorded from 2010 to 2016 were in the age range of $60-80$. In the 60-80 age group the most common symptoms recorded were: hypertension, cardiac arrhythmia, angina pectoris, as well as myocardial infarction. It can be considered that this age group is at an increased risk of developing serious cardiovascular diseases. Among those living in Rìga and regions of Latvia, it is clearly important for all to eat healthily, but comments of the respondents showed that the opposite was common.

Concerning the question about patient awareness regarding trans fatty acids, both women and men were unaware or ill-informed, which led to the conclusion that patients do not have clear understanding of TFA and their effect upon cardiovascular health and CVD. Most of the respondents stated that trans fatty acids are industrially transformed into fats, but very few said that those are fats, proteins, or cellulose.

In the next set of questions regarding trans fatty acids effect on cardiovascular disease, both men and women believed TFA to be unhealthy. Responses to the set of questions on trans fatty acids effect on changes in the lipid profile showed that the majority of patients were unaware of the distinction between LDL-C and HDL-C and believed that both were as equally harmful to the body; the majority of patients were even unaware of how to answer this question (mainly negative answers dominated). An equal number of men and women believed that trans fatty acids could be the reason for sudden cardiac arrest, and that trans fatty acids cannot have effect on sudden cardiac arrest. 
Further questions confirmed that patients read information placed on products and that it is important for them to know the exact content of the product. Thus, respondents considered that manufacturers should show trans fatty acid presence/absence on the food products even in the cases when they are not there. In the final question non choice of products with "contains trans fatty acids" on the label, the majority of the patients considered that this information would change their choice.

Overall, analysis of the data obtained in the questionnaires indicated that the majority of the respondents were unaware or ill-informed about trans fatty effects, and a low number of patients were aware of the potential threats on cardiovascular diseases. It was important for the patients to eat healthily, but there were doubts as to what food to choose in order not to harm yourself, as it can be unclear as to what harmful substances are present in a product due to unclear packaging or even missing information. After completion of the questionnaire, the researcher discussed the results of the questionnaire with the patient and provided answers to additional questions on this topic.

As reported in the guidelines for cardiovascular disease prevention, developed by the Latvian Society of Cardiology, in addition to effective diagnostics and introduction of the treatment methods, it is important to emphasise the importance of preventative measures for public health preservation and promotion (Pudule et al., 2010). The main objective of the researcher in this study was not only to examine patients' awareness of trans fatty acids and their effect on cardiovascular diseases, but also, after the completion of questionnaires, to explain to each patient individually the results of the questionnaire and discuss the potential effect of the trans fatty acids on their health.

The study can serve as a basis for further research in order to determine not only the awareness of patients from the Centre of Cardiology, but also the awareness about trans fatty acids of other demographic groups. Such research is a good information carrier, which allows the researcher to judge about the people's lack of awareness of the major health concerns arising from their diet. Our main objective was to correctly and clearly inform people of the importance of a healthy diet and the effects of TFA on their health and on CVD. People need to be aware of the effect of their diet on their health and require knowledge of the contents of any products in their diet.

Drawbacks of the research. It was impossible to cross reference and compare the results with studies conducted in other countries regarding the respondent awareness of TFA, as it was the first study of its kind focused specifically on patients of a cardiology unit. There was an insufficient quantity of respondents to fully ascertain the patient awareness of TFA

Benefits of the research. Individual sessions with each respondent to discuss the total results, during the questioning as well as after the completion of the questionnaire.

Based on the average age, the target audience would be the "older" generation to whom information would be most pertinent; however, the data shows that a diet free from TFA is beneficial to all ages.

\section{REFERENCES}

Anonymous (2013-2014). Transtaukskābju noteikšana Latvijas izcelsmes pārtikā. Pārtikas drošības, dzīvnieku veselības un vides zinātniskais institūts "BIOR" [Trans-fatty acids in food of Latvian origin for human consumption. Food safety, animal health and the environment "BIOR"]. Available from:

https://www.zm.gov.1v/public/ck/files/ZM/TP\%20petijumi/ Transtauksk\%C4\%81bes_p\%C4\%93t\%C4\%ABjums.pdf (accessed 7 February 2016).

Ascherio, A., Hennekens, C. H., Buring, J. E., Master, C., Stampfer, M. J., Willett, W. C. (1994). Trans fatty acids intake and risk of myocardial infarction, 89, 941-1001.

Imamura, F., Lemaitre, R. N., King, I. B., Song, X. (2012). Novel circulating fatty acid patterns and risk of cardiovascular disease: The cardiovascular health study. Amer. J. Clin. Nutr., 96 (6), 1252-1261.

Iqbal, M. P. (2014). Trans fatty acids: A risk factor for cardiovascular disease. Pakistan J. Med. Sci., 30 (1), 194-197.

Jasti, S., Kovacs, S. (2010). Use of trans fat information on food labels and its determinants in a multiethnic college student population. J. Nutr. Educ. Behav., 42 (5), 307-314.

Krettek, A., Thorpenberg, S., Bondjers, G. (2008). Policy department economic and scientific policy. Trans fatty acids and health: A review of health hazards and existing legislation. European Parliament. Available from: http://www.vm.gov.lv/lv/aktualitates/sabiedribas_lidzdaliba/publiska_aps priesana_noteikumu_projektam_par_maksimali_piel/ (accessed 29 November 2015).

Mintāle, I., Ērglis, A., Dinne, A., Bajāre, I., Kalvelis, A., Latkovsis, G., Zakke, I. (2010). Sirds un Virtuve [Heart and Kitchen]. Latvijas Inovatīvās medicīnas fonds, Rīga. 8 lpp. (in Latvian).

Pudule, I., Villeruša, A., Grīnberga, D., Velika, B., Taube, M., Behmane, D., Dzērve, V., Prättälä, R. (2010). Latvijas iedzìvotāju veselību ietekmējošo paradumu pétījums [Health behaviour among Latvian adult population]. Veselības ekonomikas centrs, Rīga. 151 pp. (in Latvian).

Stender, S., Astrup, A., Dyerberg, J. (2014).Tracing artificial trans fat in popular foods in Europe: A market basket investigation. BMJ (British Medical Association) Open, 4 (5), e005218.

Stender, S., Dyerberg, J. (2004). The influence of trans fatty acids on health. Ann. Nutr. Metab., 48 (2), 61-66.

Trumbo, P. R.., Shimakawa, T. (2011). Tolerable upper intake levels for trans fat, saturated fat, and cholesterol. Nutr. Rev., 69 (5), 270-278

Żbikowska, A. (2010). Formation and properties of trans fatty acids: A review. Polish J. Food Nutr. Sci., 60 (2), 107-114. 
KARDIOLOGIJAS CENTRA PACIENTU INFORMĒTĪBA PAR TRANSTAUKSKĀBJU NEGATĪVO IETEKMI UZ SIRDS UN ASINSVADƯ SLIMĪBĀM

Ṇemot vērā datus par transtaukskābju ietekmi uz cilvēka veselību, it sevišḳi sirds un asinsvadu slimībām, ir ḷoti būtiski veicināt sabiedrības informētību par transtaukskābju negatīvo ietekmi uz sirds un asinsvadu slimībām. Pētījuma mērḳis bija noskaidrot kardioloğijas nodaḷas pacientu informētību par transtaukskābēm un to negatīvo ietekmi uz sirds un asinsvadu slimībām. Pētījumā piedalījās 70 Paula Stradiņa Klīniskās universitātes slimnīcas Kardiolog̣ijas centra pacienti. Kā mērīšanas instruments tika izmantota anketa, kas sastāv no 20 jautājumiem (anketa tika sagatavota un modificēta, balstoties uz jau validētu anketu). Lielākā daḷa (74\%) pacientu bija dzirdējuši un lasījuši par transtaukskābēm, taču $62 \%$ sieviešu un $54 \%$ vīriešu bija maz informēti par transtaukskābju negatīvo ietekmi uz sirds un asinsvadu slimībām. 